\title{
Role of Phase Composition of PEO Coatings on AA2024 for In-Situ LDH Growth
}

\author{
Maria Serdechnova ${ }^{1, *}$, Marta Mohedano ${ }^{2}$, Anissa C. Bouali ${ }^{1}$, Daniel Höche ${ }^{1}$, Boris Kuznetsov ${ }^{3}$, \\ Sergey Karpushenkov ${ }^{3}$, Carsten Blawert ${ }^{1}$ and Mikhail L. Zheludkevich ${ }^{1,4}$ \\ 1 Institute of Materials Research, Helmholtz-Zentrum Geesthacht, Max-Planck-Straße 1, \\ 21502 Geesthacht, Germany; anissa.bouali@hzg.de (A.C.B.); daniel.hoeche@hzg.de (D.H.); \\ carsten.blawert@hzg.de (C.B.); mikhail.zheludkevich@hzg.de (M.L.Z.) \\ 2 Departamento de Ciencia de Materiales, Facultad de Ciencias Químicas, Universidad Complutense, \\ Madrid 28040, Spain; mmohedano@quim.ucm.es \\ 3 Faculty of Chemistry, Belarusian State University, Minsk 220030, Belarus; sirob@list.ru (B.K.); \\ ksazaslavl@mail.ru (S.K.) \\ 4 Faculty of Engineering, Kiel University, Kaiserstraße 2, 24143 Kiel, Germany \\ * Correspondence: maria.serdechnova@hzg.de; Tel.: +49-415-287-1907; Fax: +49-415-287-2636 \\ Academic Editor: Alessandro Lavacchi \\ Received: 14 October 2017; Accepted: 1 November 2017; Published: 6 November 2017
}

\begin{abstract}
Plasma electrolytic oxidation (PEO) is an environmentally friendly anodizing technique leading to the formation of a ceramic-like coatings under high-voltage discharges. Layered double hydroxides (LDHs) were grown directly on $\gamma, \alpha$, and amorphous $\mathrm{Al}_{2} \mathrm{O}_{3}$ powders, respectively, in order to investigate the phase responsible for in-situ LDH growth on PEO coating. Furthermore, it is shown that LDH growth is limited by the high tortuosity of the PEO layer and the accessibility of $\mathrm{Al}(\mathrm{OH})_{4}^{-}$anions from the substrate covered with thin amorphous aluminum oxide, through the pores.
\end{abstract}

Keywords: layered double hydroxides; plasma electrolytic oxidation; aluminum alloy

\section{Introduction}

Plasma electrolytic oxidation (PEO) is an environmentally friendly anodizing process leading to the formation of ceramic-like coatings under high-voltage discharges [1]. Hard and strongly-adherent PEO layers developed on metallic substrates improve both corrosion and wear properties of the material [2]. Unfortunately, the electrical discharges and high stresses in the layer are also responsible for the formation of channels, pores from gas inclusions, and cracks in the coating. Different optimization trials (such as alternative current/voltage regimes $[3,4]$, post-treatments $[5,6]$, particle incorporation [7-9], etc.) have been performed in order to overcome this disadvantage. Currently all these treatments (e.g., immersion in phosphate, silicate or borate-containing electrolytes, as well as sol-gel, polymers, and other approaches $[6,10,11]$ ) aim to improve the long-term corrosion resistance of PEO coatings by sealing the porous structure that allowed fast penetration of corrosive species to the interface. However, the improvement of barrier properties does not always ensure a long service life of the material due to the formation of scratches, cracks, and other defects caused by exploitation. One way to avoid corrosion propagation in such defects is to use the concept of active inhibition on demand in the presence of specific triggers.

Recently, layered double hydroxides (LDHs) have been widely studied as possible green containers for the active corrosion protection of bare [12-18], pre-anodized [19,20], and PEO-coated [21,22] aluminum alloys. LDH films have been grown in-situ, intercalated with corrosion inhibitors, and used for "smart" controlled corrosion protection as a result of anion exchange between inhibiting species 
and the aggressive environment $[16,17,23,24]$. In previous works, authors have already investigated the influence of PEO thickness and $\mathrm{Al}(\mathrm{OH})_{4}^{-}$availability for the in-situ LDH growth [22]. The advantage of the PEO layer is that it includes data from both the electrolyte and the treated substrate. In the framework of this study, we have synthesized $\mathrm{Zn}-\mathrm{Al} \mathrm{LDH}$ on the surface and in the pores of the PEO coating as a first step and then analyzed the role of its phase composition. The behavior of $\alpha, \gamma$, and amorphous aluminum oxide was checked, and their impact on LDH growth is discussed.

\section{Experimental}

\subsection{Materials}

The list of materials used for this work is: Zinc nitrate hexahydrate $\left(\mathrm{Zn}\left(\mathrm{NO}_{3}\right)_{2} \cdot 6 \mathrm{H}_{2} \mathrm{O},>99 \%\right.$, CarlRoth, Karlsruhe, Germany), ammonium nitrate $\left(\mathrm{NH}_{4} \mathrm{NO}_{3},>98.5 \%\right.$, Bernd Kraft, Duisburg, Germany), ammonia solution $\left(\mathrm{NH}_{3} \cdot \mathrm{H}_{2} \mathrm{O}, 25 \%\right.$, Merck KGaA, Darmstadt, Germany), sodium vanadate oxide $\left(\mathrm{NaVO}_{3}, 96 \%\right.$, AlfaAesar, Karlsruhe, Germany), sodium metasilicate $\left(\mathrm{Na}_{2} \mathrm{SiO}_{3}, 44 \%-47 \% \mathrm{SiO}_{2}\right.$, Sigma-Aldrich Chemie $\mathrm{GmbH}$, Schnelldorf, Germany), sodium hydroxide $(\mathrm{NaOH},>99 \%$, Merck $\mathrm{KGaA}$, Germany), sodium dihydrogen phosphate $\left(\mathrm{Na}_{2} \mathrm{H}_{2} \mathrm{P}_{2} \mathrm{O}_{7}, 98 \%\right.$, Chempur, Karlsruhe, Germany), and nitric acid $\left(\mathrm{HNO}_{3}, 65 \%\right.$, Merck, Darmstadt, Germany). Metallic aluminum powder (ca. $1 \mu \mathrm{m}$, MP-Al), $\gamma-\mathrm{Al}_{2} \mathrm{O}_{3}\left(1-2 \mu \mathrm{m}\right.$, gamma- $\left.\mathrm{Al}_{2} \mathrm{O}_{3}\right)$, and $\alpha-\mathrm{Al}_{2} \mathrm{O}_{3}\left(1-2 \mu \mathrm{m}\right.$, alpha- $\left.\mathrm{Al}_{2} \mathrm{O}_{3}\right)$ were purchased from EdgeTech Industries LLC (Miramar, FL, USA). Deionized water was used as a solvent.

\subsection{Methods}

AA2024 aluminum alloy with a nominal composition of (wt \%): $3.8-4.9 \mathrm{Cu}, 0.5 \mathrm{Fe}, 0.1 \mathrm{Cr}$, $1.2-1.8 \mathrm{Mg}, 0.3-0.9 \mathrm{Mn}, 0.5 \mathrm{Si}, 0.15 \mathrm{Ti}, 0.25 \mathrm{Zn}, 0.15$ others, and Al balance-was used as substrate. The surface pre-treatment was performed according to the procedure previously described by Kuznetsov et al. [19]. Briefly, the AA2024 samples were first cleaned in Metaclean T1200 solution for $25 \mathrm{~min}$ at $68^{\circ} \mathrm{C}$ followed by an alkaline etching in Turco Liquid Aluminetech $\mathrm{N} 2$ for $45 \mathrm{~s}$ at $60{ }^{\circ} \mathrm{C}$, and finally an acid etching in Turco Liquid Smutgo NC for 7 min at $30^{\circ} \mathrm{C}$.

The PEO processing was performed in aqueous electrolyte with parameters presented in Table 1 following the methodology described by different groups and adopted from [19,25-27].

Table 1. Plasma electrolytic oxidation (PEO) processing parameters.

\begin{tabular}{c|c|c}
\hline Parameter & PEO & Amorphous PEO \\
\hline Voltage (Constant) & $450 \mathrm{~V}$ & $250 \mathrm{~V}, 350 \mathrm{~V}, 450 \mathrm{~V}$ \\
\hline Time & \multicolumn{2}{|c}{$15 \mathrm{~min}$} \\
\hline & $9 \mathrm{~g} \cdot \mathrm{L}^{-1} \mathrm{Na}_{2} \mathrm{SiO}_{3}$ & $20 \mathrm{~g} \cdot \mathrm{L}^{-1} \mathrm{Na}_{2} \mathrm{SiO}_{3}$ \\
Electrolyte & $2 \mathrm{~g} \cdot \mathrm{L}^{-1} \mathrm{NaOH}$ & $3 \mathrm{~g} \cdot \mathrm{L}^{-1} \mathrm{NaOH}$ \\
& $11 \mathrm{~g} \cdot \mathrm{L}^{-1} \mathrm{Na}_{2} \mathrm{H}_{2} \mathrm{P}_{2} \mathrm{O}_{7}$ & $20 \mathrm{~g} \cdot \mathrm{L}^{-1} \mathrm{Na}_{3} \mathrm{PO}_{4}$ \\
\hline Maximum Average Current Density & $50 \mathrm{~mA} / \mathrm{cm}^{2}$ & $70 \mathrm{~mA} / \mathrm{cm}^{2}$ \\
\hline Pulse Ratio (ton:toff) & \multicolumn{2}{|c}{$1 \mathrm{~ms}: 9 \mathrm{~ms}$} \\
\hline Temperature & $20 \pm 2{ }^{\circ} \mathrm{C}$ \\
\hline Size & $20 \mathrm{~mm} \times 30 \mathrm{~mm} \times 2 \mathrm{~mm}$ & $26 \mathrm{~mm} \times 36 \mathrm{~mm} \times 2 \mathrm{~mm}$ \\
\hline
\end{tabular}

The synthesis of $\mathrm{Zn}-\mathrm{Al}$ LDH-nitrate (PEO-LDH-NO ${ }_{3}$ ) and $\mathrm{Zn}-\mathrm{Al} \mathrm{LDH}-\mathrm{vanadate}\left(\mathrm{PEO}-\mathrm{LDH}-\mathrm{VO}_{x}\right.$ ) on the surface of PEO-treated AA2024 were performed according to the methodology previously described [17,19]: (1) PEO-LDH-NO $\mathrm{N}_{3}$ was grown in a solution of $\mathrm{Zn}\left(\mathrm{NO}_{3}\right)_{2} \cdot 6 \mathrm{H}_{2} \mathrm{O}(0.1 \mathrm{M})$ and $\mathrm{NH}_{4} \mathrm{NO}_{3}$ $(0.6 \mathrm{M})$ (pH adjusted to $6.5 \mathrm{using} 1 \%$ ammonia) under $95^{\circ} \mathrm{C}$ for $30 \mathrm{~min}$ and (2) vanadate intercalation was performed via anion exchange reaction in a solution of $0.1 \mathrm{M} \mathrm{NaVO}_{3}$ at $\mathrm{pH} 8.4\left(50^{\circ} \mathrm{C}\right.$ for $30 \mathrm{~min}$ ).

The synthesis of $\mathrm{LDH}-\mathrm{NO}_{3}$ using three different aluminum oxide-containing powders (metallic aluminum covered with natural oxide film, $\gamma-\mathrm{Al}_{2} \mathrm{O}_{3}$ and $\alpha-\mathrm{Al}_{2} \mathrm{O}_{3}$ ) as potential source of aluminum cations was carried out using the same method described above; $0.5 \mathrm{~g}$ of each powder was added to 
a solution of $0.1 \mathrm{M} \mathrm{Zn}\left(\mathrm{NO}_{3}\right)_{2}$ and $0.6 \mathrm{M} \mathrm{NH}_{4} \mathrm{NO}_{3}$ at $\mathrm{pH} 6.5,95{ }^{\circ} \mathrm{C}$ for $30 \mathrm{~min}$. The resulting powders were centrifuged, rinsed with deionized water, and dried under $60^{\circ}$ for $4 \mathrm{~h}$.

\subsection{Characterizations}

Planar views and cross-sections of coatings were examined with a Tescan Vega3 SB scanning electron microscope (SEM, Brno, Czech Republic) equipped with an energy dispersive X-ray (EDS) spectrometer (eumeX Instrumentebau $\mathrm{GmbH}$, Heidenrod, Germany). Phases observed on the PEO-coated samples were characterized by grazing incidence $X$-ray measurements using a PANalytical $X^{\prime}$ Pert Powder diffractometer (Karlsruhe, Germany) (Ni-filtered $\mathrm{Cu} \mathrm{K} \alpha$ radiation, step size $0.02^{\circ}$, dwell time $\sim 1.5 \mathrm{~s})$ at room temperature in $\theta-\theta$ geometry. Incident angle was set to $3^{\circ}$.

\section{Results and Discussion}

In order to analyze the LDH layer on the surface, grazing incidence angle XRD (GIXRD) was performed. The measured diffraction patterns of PEO without any $\mathrm{LDH}, \mathrm{PEO}$ coated with $\mathrm{LDH}-\mathrm{NO}_{3}$, and PEO with $\mathrm{LDH}-\mathrm{VO}_{x}$ are shown in Figure 1a.
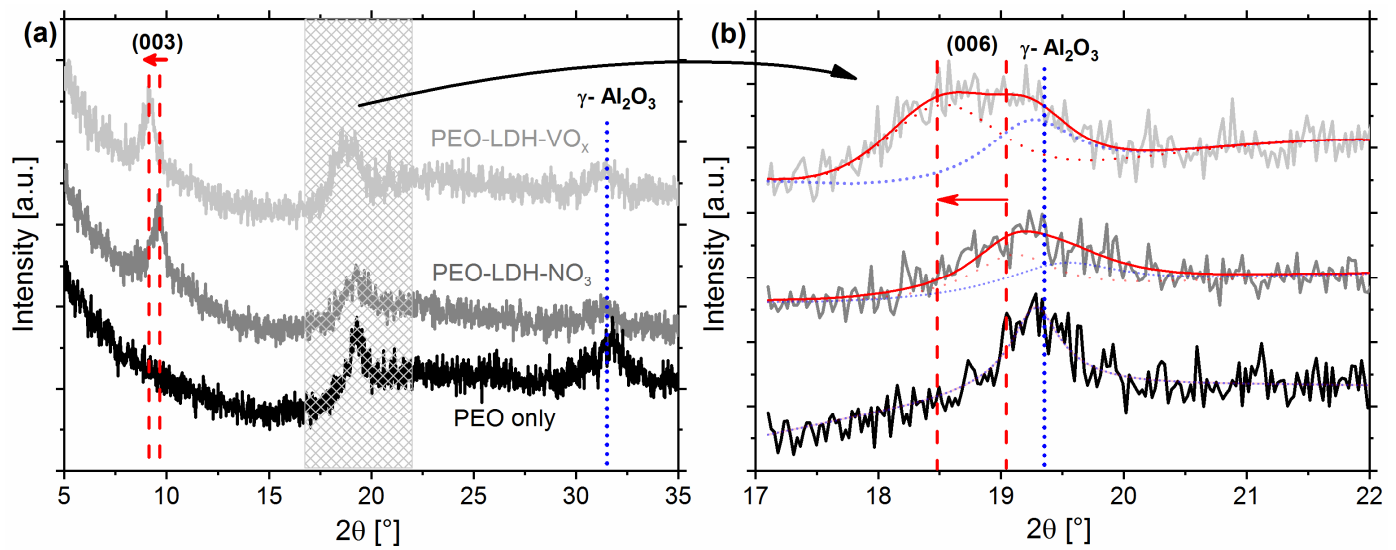

Figure 1. (a) Grazing incidence $\left(3^{\circ}\right)$ X-ray diffraction patterns of the PEO sample, PEO sample with $\mathrm{Zn}$-Al layered double hydroxide-nitrate $\left(\mathrm{LDH}-\mathrm{NO}_{3}\right)$, PEO sample with $\mathrm{Zn}$-Al LDH-vanadate $\left(\mathrm{LDH}-\mathrm{VO}_{x}\right)$. (b) Overlapping peak deconvolution via enhanced peak fitting.

The XRD pattern of PEO treated sample shows two peaks at $19.1^{\circ}$ and $31.9^{\circ}$ which correspond to $\gamma-\mathrm{Al}_{2} \mathrm{O}_{3}$ found in the PEO layer. There is also a broadened signal in the range of $17-30^{\circ}$ due to the presence of $\mathrm{Al}_{2} \mathrm{O}_{3}$ in amorphous or nano-crystalline form. No peak of $\alpha-\mathrm{Al}_{2} \mathrm{O}_{3}$ (normally at 25.6 [28]) was detected in the $\mathrm{XRD}$ pattern.

For PEO-LDH-NO ${ }_{3}$, the $\mathrm{XRD}$ pattern shows a peak at $9.5^{\circ}$ which is due to the (003) reflection of LDH [29]. These reflections correspond to a basal spacing of $9.1 \AA$, and given that the total thickness of $\mathrm{Zn} / \mathrm{Al}$ hydroxide layer is about $4.7 \AA$ [26], the space available for $\mathrm{NO}_{3}{ }^{-}$corresponds to approximately $4.4 \AA$. The (006) peak of $\mathrm{LDH}-\mathrm{NO}_{3}$ is overlapped with the reflection of $\gamma-\mathrm{Al}_{2} \mathrm{O}_{3}$. Thus, the signals were deconvoluted via fitting of two Pearson VII peaks, as shown in Figure $1 \mathrm{~b}$.

After the anion exchange reaction between nitrate and vanadate anions, the peak positions in the XRD pattern shifted as indicated by an arrow in Figure 1b. Both (003) and (006) peaks of $\mathrm{LDH}^{-\mathrm{VO}_{x} \text { are }}$ detected at $9.1^{\circ}$ and $18.5^{\circ}$ respectively. The shift in the peaks of $\mathrm{LDH}-\mathrm{VO}_{x}$ is due to an increase in the gallery height from $4.4 \AA$ to $4.9 \AA \mathrm{d}(003)$ at $9.5 \AA$ to $\mathrm{d}(003)$ at $9.1 \AA$, respectively. No clear assignable diffraction pattern corresponding to the $\mathrm{LDH}-\mathrm{NO}_{3}$ was detected after the anion exchange reaction.

The morphology of original PEO-treated AA2024 surface as well as LDH flakes formed on PEO was investigated using SEM. Figure 2 shows a plan view SEM micrographs of as-prepared PEO and PEO-LDH-NO $\mathrm{NO}_{3}$ specimens. The PEO sample (Figure 2a) shows the typical surface morphology of plasma electrolytic oxidation layers with pores and cracks at the discharge channel sites, due to 
the thermal stresses and gas evolution through the molten oxide material during the PEO process, respectively [1].
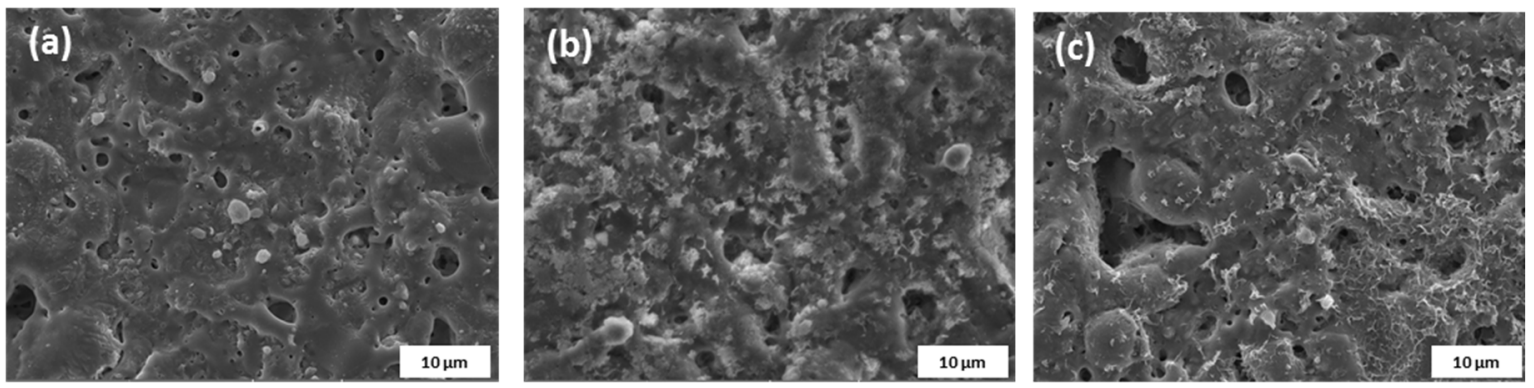

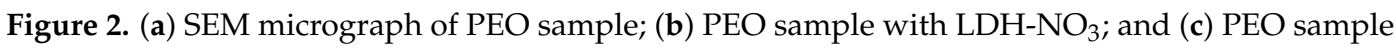
with $\mathrm{LDH}_{-} \mathrm{VO}_{x}$.

Synthesis of $\mathrm{LDH}-\mathrm{NO}_{3}$ on the PEO-coated AA2024 specimen led to the coverage of the surface with a layer of flake-like microstructures (Figure $2 b$ ). These flakes are significantly smaller in comparison with those previously published for TSA (tartaric sulfuric acid anodization)-treated surface (200-400 nm vs. 1-5 $\mu \mathrm{m}$ for TSA treatment) [20]. Thus, growth-limiting factors must determine the LDH formation process. Based on recent studies, the following explanation can be proposed. $\mathrm{Zn}-\mathrm{Al}$ $\mathrm{LDH}$ synthesis is based on the following chemical reactions [30]:

$$
\begin{gathered}
\mathrm{Al}_{2} \mathrm{O}_{3}+3 \mathrm{H}_{2} \mathrm{O}+2 \mathrm{OH}^{-} \rightarrow 2 \mathrm{Al}(\mathrm{OH})_{4}^{-} \\
\mathrm{Zn}^{2+}+\mathrm{OH}^{-} \rightarrow \mathrm{Zn}(\mathrm{OH})^{+} \\
\mathrm{Zn}(\mathrm{OH})^{+}+\mathrm{Al}(\mathrm{OH})_{4}^{-}+\mathrm{NO}_{3}{ }^{-}+\mathrm{H}_{2} \mathrm{O} \rightarrow \mathrm{LDH}^{-} \mathrm{NO}_{3}
\end{gathered}
$$

The LDH growth strongly depends on the dissolution of $\mathrm{Al}_{2} \mathrm{O}_{3}$ both from the bulk of the PEO coating $\left(\gamma-\mathrm{Al}_{2} \mathrm{O}_{3}+\right.$ amorphous $\mathrm{Al}_{2} \mathrm{O}_{3}$ in this case) and/or amorphous $\mathrm{Al}_{2} \mathrm{O}_{3}$ from inner PEO layer (Figure 3). The complex surface system, containing PEO pores and cracks, limits species (ion) transport; the direct dissolution of aluminum from the substrate is suppressed. The smaller size of the LDH flakes on the present PEO system can be explained by the lower accessibility of $\mathrm{Al}(\mathrm{OH})_{4}^{-}$. For the PEO system, the porosity $\varepsilon$ and the tortuosity $\tau$ of the coating (which limit the diffusion for thicker PEO layer systems) should be considered. The tortuosity- "connectivity" — describes the accessibility of the electrolyte to the surface, and is a factor to quantify the interconnection of pores, channels, and cracks ( $\tau=1$ for an infinitely small layer thickness). For typical pore structures, it is between 1.33 and 4 , and is related to the porosity via the Bruggeman relation [31]. From the presented results of LDH growth, one can conclude that either the tortuosity of the PEO layer is significantly higher than for TSA layer and/or the Al-containing phases of the PEO layer are not suitable for LDH growth.

The second assumption mentioned above is further verified by $X R D$ analysis of $\gamma-\mathrm{Al}_{2} \mathrm{O}_{3}, \alpha-\mathrm{Al}_{2} \mathrm{O}_{3}$, and metallic aluminum (MP-Al) powders after attempting to grow $\mathrm{LDH}-\mathrm{NO}_{3}$ on them (Figure $4 \mathrm{a}$ ). The characteristic peaks at $9.9^{\circ}$ and $19.8^{\circ}$ corresponding to the reflections (003) and (006), respectively, attesting the presence of $\mathrm{LDH}-\mathrm{NO}_{3}$ can be only seen on the metallic aluminum powder which was covered with natural amorphous aluminum oxide. These peaks are not present for both $\gamma-\mathrm{Al}_{2} \mathrm{O}_{3}$ and $\alpha-\mathrm{Al}_{2} \mathrm{O}_{3}$, which suggests that the growth of $\mathrm{LDH}-\mathrm{NO}_{3}$ could not be achieved on crystalline $\gamma-\mathrm{Al}_{2} \mathrm{O}_{3}$ and $\alpha-\mathrm{Al}_{2} \mathrm{O}_{3}$. 


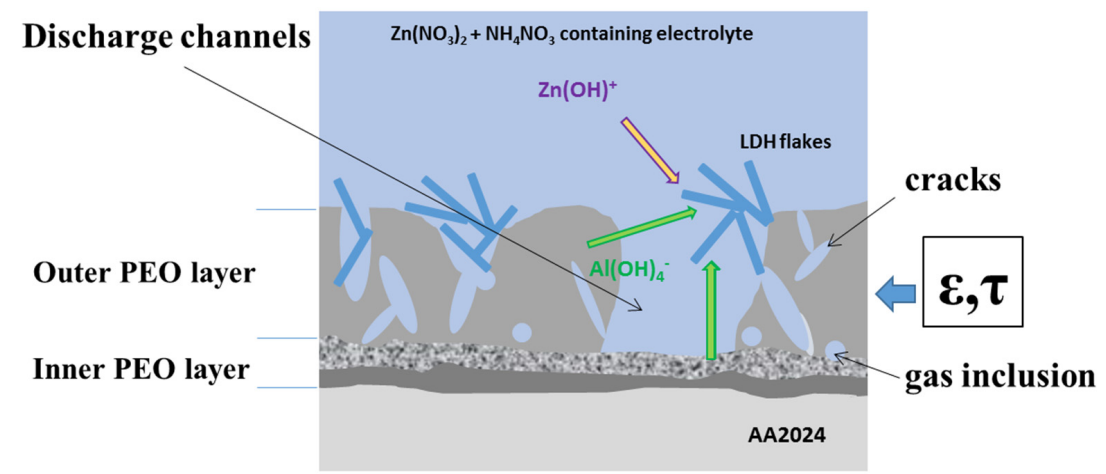

Figure 3. The schematic presentation of $\mathrm{Al}(\mathrm{OH})_{4}^{-}$availability for the $\mathrm{LDH}$ growth.

a)

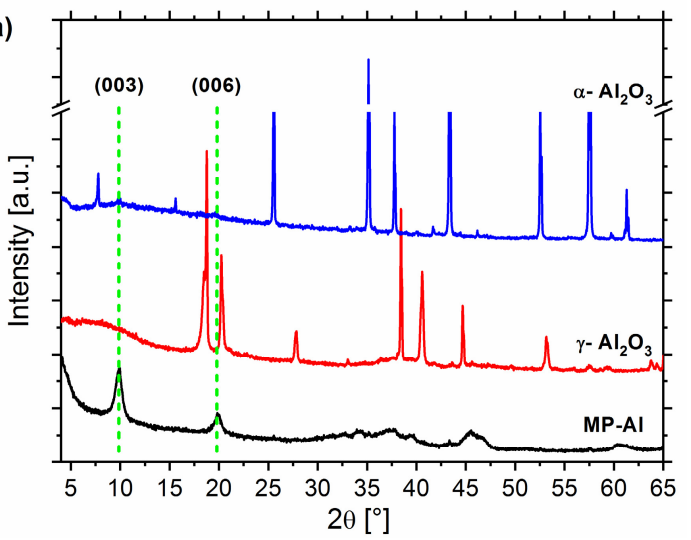

b)

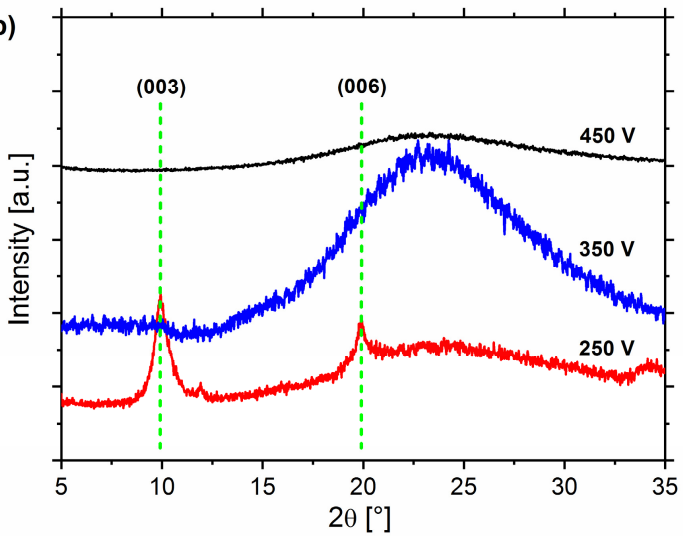

Figure 4. (a) X-ray diffraction patterns of the metallic powder $\mathrm{Al}(\mathrm{MP}-\mathrm{Al}), \gamma-\mathrm{Al}_{2} \mathrm{O}_{3}$, and $\alpha-\mathrm{Al}_{2} \mathrm{O}_{3}$ after attempting to grow $\mathrm{LDH}_{-} \mathrm{NO}_{3}$ on them; and (b) AA2024 alloy with PEO formed at $250 \mathrm{~V}, 350 \mathrm{~V}$, and $450 \mathrm{~V}$ after attempting to grow $\mathrm{LDH}-\mathrm{NO}_{3}$.

In order to check whether all aluminum oxides in amorphous state are suitable for LDH synthesis, the PEO treatment of AA2024 under $250 \mathrm{~V}, 350 \mathrm{~V}$, and $450 \mathrm{~V}$ was performed in a different electrolyte (see Table 1). The conditions were chosen in order to form amorphous layers with different thicknesses but not crystalline phases. The XRD patterns for the samples after growth of LDH are presented in Figure $4 \mathrm{~b}$. It can be seen that the $\mathrm{LDH}-\mathrm{NO}_{3}$ only grew on the sample treated under $250 \mathrm{~V}$ (average thickness 1-2 $\mu \mathrm{m}$ ), but not on the samples prepared at $350 \mathrm{~V}$ and $450 \mathrm{~V}$ (with average thicknesses of about 30 and $50 \mu \mathrm{m}$, respectively). These results, together with reduced size of LDH flakes shown in Figure 2, clearly confirm that for the investigated layered systems the predominant source of aluminum cation is the $\mathrm{Al}$ substrate through the $\mathrm{PEO}$ pores. The availability of aluminum cations is strictly limited by the access of electrolyte to the substrate interface and a possible reaction between $\mathrm{Zn}(\mathrm{OH})^{+}$and $\mathrm{Al}(\mathrm{OH})_{4}^{-}$.

\section{Conclusions}

The part played by $\gamma, \alpha$, and amorphous $\mathrm{Al}_{2} \mathrm{O}_{3}$ composing the PEO coating on the in-situ growth of $\mathrm{LDH}$ is analyzed in the frame of the current work. It is shown that crystalline $\gamma-\mathrm{Al}_{2} \mathrm{O}_{3}$ and $\alpha-\mathrm{Al}_{2} \mathrm{O}_{3}$ cannot be dissolved and used as source for LDH formation, while natural amorphous oxide layer and inner layer, obtained during PEO treatment, can be. The LDH growth is strictly limited by high tortuosity of $\mathrm{PEO}$ layer and accessibility of $\mathrm{Al}(\mathrm{OH})_{4}^{-}$anions dissolved from the substrate. A compromise between the barrier properties of the PEO layer (higher thickness) and the growth of LDH for active protection (thinner layer) should be reached. For future works, the accurate identification of phases (e.g., boehmite as main component of natural aluminum oxide layer) suitable for LDH growth should be performed. 
Acknowledgments: This work was partially supported by MULTISURF (Marie Skłodowska-Curie grant agreement No. 645676) European project. Marta Mohedano is grateful to the MINECO (Spain) for financial support via Young Researchers Challenges Programme MAT2015-73355-JIN (Proyectos Retos Jovenes Investigadores).

Author Contributions: Sergey Karpushenkov and Carsten Blawert performed PEO treatments of AA2024; Marta Mohedano characterized PEO coatings, Boris Kuznetsov grew LDH on the surface of PEO treated AA2024, Anissa C. Bouali and Maria Serdechnova synthesized LDH of powders, Daniel Höche performed XRD characterization, Maria Serdechnova and Mikhail L. Zheludkevich analyzed data and wrote the paper.

Conflicts of Interest: The authors declare no conflict of interests.

\section{References}

1. Yerokhin, A.L.; Nie, X.; Leyland, A.; Matthews, A.; Dowey, S.J. Plasma electrolysis for surface engineering. Surf. Coat. Technol. 1999, 122, 73-93. [CrossRef]

2. Curran, A.; Clyne, T.W. Thermo-physical properties of plasma electrolytic oxide coatings on aluminium. Surf. Coat. Technol. 2005, 199, 168-179. [CrossRef]

3. Matykina, E.; Arrabal, R.; Skeldon, P.; Thompson, G.E. Investigation of the growth processes of coatings formed by AC plasma electrolytic oxidation of aluminium. Surf. Coat. Technol. 2009, 54, 6767-6778. [CrossRef]

4. Mertsalo, I.P.; Yavors'kyi, V.T.; Klapkiv, M.D.; Mardarevych, R.S. Wear resistance of anodic-spark coatings on aluminum alloys. Mater. Sci. 2003, 39, 136-139. [CrossRef]

5. Wang, Z.; Wu, L.; Qi, Y.; Cai, W.; Jiang, Z. Self-lubricating $\mathrm{Al}_{2} \mathrm{O}_{3}$ /PTFE composite coating formation on surface of aluminium alloy. Surf. Coat. Technol. 2010, 204, 3315-3318. [CrossRef]

6. Mohedano, M.; Matykina, E.; Arrabal, R.; Mingo, B.; Pardo, A. PEO of pre-anodized Al-Si alloys: Corrosion properties and influence of sealings. Appl. Surf. Sci. 2015, 346, 57-67. [CrossRef]

7. Lu, X.; Sah, S.P.; Scharnagl, N.; Störmer, M.; Starykevich, M.; Mohedano, M.; Blawert, C.; Zheludkevich, M.L.; Kainer, K.U. Degradation behavior of PEO coating on AM50 magnesium alloy produced from electrolytes with clay particle addition. Surf. Coat. Technol. 2015, 269, 155-169. [CrossRef]

8. Lu, X.; Blawert, C.; Kainer, K.U.; Zheludkevich, M.L. Investigation of the formation mechanisms of plasma electrolytic oxidation coatings on Mg alloy AM50 using particles. Electrochim. Acta 2016, 196, 680-691. [CrossRef]

9. Lu, X.; Blawert, C.; Huang, Y.; Ovri, H.; Zheludkevich, M.L.; Kainer, K.U. Plasma electrolytic oxidation coatings on $\mathrm{Mg}$ alloy with addition of $\mathrm{SiO}_{2}$ particles. Electrochim. Acta 2016, 187, 20-33. [CrossRef]

10. Chen, M.; Liu, S.; Li, J.; Cheng, N.; Zhang, X. Improvement to corrosion resistance of MAO coated 2519 aluminum alloy by formation of polypropylene film on its surface. Surf. Coat. Technol. 2013, 232, 674-679. [CrossRef]

11. Shrestha, S.; Merstallinger, A.; Sickert, D.; Dunn, B.D. Preliminary evaluation of black coating on AA2219 alloy produced by plasma electrolytic oxidation (PEO) process for space applications. In Proceedings of the 9th International Symposium on Materials in a Space Environment, ISMSE 2003, Noordwijk, The Netherlands, 16-20 June 2003; pp. 57-65.

12. Tedim, J.; Zheludkevich, M.L.; Salak, A.N.; Lisenkov, A.; Ferreira, M.G.S. Nanostructured LDH-container layer with active protection functionality. J. Mater. Chem. 2011, 21, 15464-15470. [CrossRef]

13. Wang, Y.; Zhang, D.; Lu, Z. Hydrophobic Mg-Al layered double hydroxide film on aluminum: Fabrication and microbiologically influenced corrosion resistance properties. Colloids Surf. A 2015, 474, 44-51. [CrossRef]

14. Zhou, M.; Pang, X.; Wei, L.; Gao, K. Insitu grown superhydrophobic Zn-Al layered double hydroxides films on magnesium alloy to improve corrosion properties. Appl. Surf. Sci. 2015, 337, 172-177. [CrossRef]

15. Scarpellini, D.; Falconi, C.; Gaudio, P.; Mattoccia, A.; Medaglia, P.G.; Orsini, A.; Pizzoferrato, R.; Richetta, M. Morphology of $\mathrm{Zn} / \mathrm{Al}$ layered double hydroxide nanosheets grown onto aluminum thin films. Microelectron. Eng. 2014, 126, 129-133. [CrossRef]

16. Serdechnova, M.; Kallip, S.; Ferreira, M.G.S.; Zheludkevich, M.L. Active self-healing coating for galvanically coupled multi-material assemblies. Electrochem. Commun. 2014, 41, 51-54. [CrossRef]

17. Zheludkevich, M.L.; Tedim, J.; Ferreira, M.G.S. "Smart" coatings for active corrosion protection based on multi-functional micro and nanocontainers. Electrochim. Acta 2012, 82, 314-323. [CrossRef]

18. Collazo, A.; Hernández, M.; Nóvoa, X.R.; Pérez, C. Effect of the addition of thermally activated hydrotalcite on the protective features of sol-gel coatings applied on AA2024 aluminium alloys. Electrochim. Acta 2011, 56, 7805-7814. [CrossRef] 
19. Kuznetsov, B.; Serdechnova, M.; Tedim, J.; Starykevich, M.; Kallip, S.; Oliveira, M.P.; Hack, T.; Nixon, S.; Ferreira, M.G.S.; Zheludkevich, M.L. Sealing of tartaric sulfuric (TSA) anodized AA2024 with nanostructured LDH layers. RSC Adv. 2016, 6, 13942-13952. [CrossRef]

20. Li, Y.; Li, S.; Zhang, Y.; Yu, M.; Liu, J. Enhanced protective Zn-Al layered double hydroxide film fabricated on anodized 2198 aluminum alloy. J. Alloys Compd. 2015, 630, 29-36. [CrossRef]

21. Serdechnova, M.; Mohedano, M.; Kuznetsov, B.; Mendis, C.L.; Starykevich, M.; Karpushenkov, S.; Tedim, J.; Ferreira, M.G.S.; Blawert, C.; Zheludkevich, M.L. PEO coatings with active protection based on in-situ formed LDH-nanocontainers. J. Electrochem. Soc. 2017, 164, C36-C45. [CrossRef]

22. Mohedano, M.; Serdechnova, M.; Starykevich, M.; Karpushenkov, S.; Bouali, A.C.; Ferreira, M.G.S.; Zheludkevich, M.L. Active protective PEO coatings on AA2024: Role of voltage on in-situ LDH growth. Mater. Des. 2017, 120, 36-46. [CrossRef]

23. Hang, T.T.X.; Truc, T.A.; Duong, N.T.; Pébère, N.; Olivier, M.-G. Layered double hydroxides as containers of inhibitors in organic coatings for corrosion protection of carbon steel. Prog. Org. Coat. 2012, 74, 343-348. [CrossRef]

24. Hang, T.T.X.; Truc, T.A.; Duong, N.T.; Vu, P.G.; Hoang, T. Preparation and characterization of nanocontainers of corrosion inhibitor based on layered double hydroxides. Appl. Clay Sci. 2012, 67-68, 18-25. [CrossRef]

25. Yerokhin, A.L.; Shatrov, A.; Samsonov, V.; Shashkov, P.; Pilkington, A.; Leyland, A.; Matthews, A. Oxide ceramic coatings on aluminium alloys produced by a pulsed bipolar plasma electrolytic oxidation process. Surf. Coat. Technol. 2005, 199, 150-157. [CrossRef]

26. Barik, R.C.; Wharton, J.A.; Wood, R.J.K.; Stokes, K.R.; Jones, R.L. Corrosion, erosion and erosion-corrosion performance of plasma electrolytic oxidation (PEO) deposited $\mathrm{Al}_{2} \mathrm{O}_{3}$ coatings. Surf. Coat. Technol. 2005, 199, 158-167. [CrossRef]

27. Parfenov, E.V.; Yerokhin, A.; Matthews, A. Small signal frequency response studies for plasma electrolytic oxidation. Surf. Coat. Technol. 2009, 203, 2896-2904. [CrossRef]

28. Feret, F.R.; Roy, D.; Boulanger, C. Determination of alpha and beta alumina in ceramic alumina by X-ray diffraction. Spectrochim. Acta Part B 2000, 55, 1051-1061. [CrossRef]

29. Brindley, G.W.; Kao, C.C. Structural and IR relations among brucite-like divalent metal hydroxides. Phys. Chem. Miner. 1984, 10, 87-191. [CrossRef]

30. Galvão, T.L.P.; Neves, C.S.; Caetano, A.P.F.; Maia, F.; Mata, D.; Malheiro, E.; Ferreira, M.J.; Bastos, A.C.; Salak, A.N.; Gomes, J.R.B.; et al. Control of crystallite and particle size in the synthesis of layered double hydroxides: Macromolecular insights and a complementary modeling tool. J. Colloid Interface Sci. 2016, 468, 86-94. [CrossRef] [PubMed]

31. Cussler, E.L. Diffusion: Mass Transfer in Fluid Systems; Cambridge University Press: Cambridge, UK, 2009; p. 647.

(C) 2017 by the authors. Licensee MDPI, Basel, Switzerland. This article is an open access article distributed under the terms and conditions of the Creative Commons Attribution (CC BY) license (http://creativecommons.org/licenses/by/4.0/). 